\title{
OCUPAREA PE PLATFORMELE DIGITALE ÎN CONTEXTUL CRIZEI COVID-19: STUDIU DE CAZ ASUPRA PERSONALULUI DE LIVRARE
}

DELIA BĂDOI

\begin{abstract}
$A$ rticolul își propune o analiză critică asupra implicațiilor precarităţii economice, în ceea ce privește ocuparea forței de muncă pe platformele digitale de livrare de produse. Contextul politicilor recente de ocupare și criza provocată de virusul COVID19 pe piața muncii au adus subiectul ocupării digitale pe agenda publică. $\hat{I}$ Ină, la nivel academic, subiectul a fost analizat sporadic, marginalizând aspecte importante ale riscurilor și vulnerabilităților asociate procesului accelerat de precarizare a muncii digitale. Așadar, prin combinarea diferitelor unghiuri analitice, cu accente asupra condițiilor de vulnerabilitate economică și socială a lucrătorilor din industria livrării, articolul analizează sintetic asocierea dintre precaritatea muncii, digitalizarea provocată de COVID-19 și fenomenul de flexibilizare influențat de politicile recente de ocupare. In demonstrația propusă sunt două abordări: în primul rând, articolul va oferi informații despre contextul politic și economic al pieței muncii din România, dinainte de criza pandemiei COVID-19 și va analiza situația ocupării precare și a politicii salariului minim. In al doilea rând, articolul se va centra pe ocuparea digitalizată prin intermediul platformelor din România, luând ca studiu de caz personalul de livrare aflat în linia întâi de expunere la virusul COVID-19.

Cuvinte-cheie: precaritate; platforme digitale; flexibilitate; COVID19; salariul minim.
\end{abstract}

\section{INTRODUCERE}

Articolul își propune o analiză sintetică a fenomenului de flexibilizare a muncii intermediate de platformele digitale din România. Contextele politice și economice de după perioada crizei economice din 2009 și mai recent, al crizei pandemiei provocate de virusul COVID-19 au produs apariția unor schimbări legislative la nivelul organizării muncii digitale. Printre acestea, consolidarea politicilor neoliberale de ocupare flexibilă a avut efecte directe asupra procesului de precarizare a calității vieții de muncă (Harvey, 2005; Ban, 2016). În ultimele

\footnotetext{
Adresa de contact a autorului: Delia Bădoi, Institutul de Cercetare a Calităţii Vieţii al Academiei Române, Calea 13 Septembrie, nr. 13, sector 5, 050711, Bucureşti, România, e-mail: delia.georgiana.badoi@gmail.com.
} 
decenii, înainte de criza cauzată de COVID-19, politicile ocupării, împreună cu schimbările legislative nefavorabile și insuficiente pentru a asigura protecția socială și reprezentarea colectivă ale lucrătorilor cu contracte de muncă flexibilă (Trif, 2013; 2016; Adăscăliţei, 2018) au provocat o dezvoltare polarizantă a pieței muncii, cu o segmentare profundă a veniturilor, îndeosebi la nivelul grupurilor vulnerabile (Standing, 2011; Vallas, 2015; Kalleberg, 2009; 2011).

Reformele legislative din ultimul deceniu au adus pe agenda politică necesitatea digitalizării muncii, prin libertatea de organizare a timpului și a condițiilor de muncă la distanță. În aceeași măsură, fenomenul digitalizării a normalizat un efect ascuns al precarizării muncii, prin insecuritatea ocupării pe termen lung şi prin politica salariului minim.

Fenomenul muncii digitale intermediate de platforme în România reprezintă un element de noutate în cadrul politicilor de ocupare, care au fost accelerate de pandemia COVID-19 din 2020, când o mare parte dintre activitățile profesionale au fost mutate în mediul online. Noile tehnologii ale automatizării muncii funcționează prin calcule efectuate de algoritmi digitali care măsoară productivitatea muncii și care organizează condițiile de muncă la distanţă și pe perioade flexibile de timp.

Prezentul articol pornește de la discursul neoliberal asupra schimbărilor politice şi economice ale ocupării în contextul actual al digitalizării și flexibilizării muncii. Articolul tratează ca studiu de caz munca digitală din sectorul livrării de produse alimentare, explicată din perspectiva teoretică a conceptului de 'precaritate', definit prin trei tipuri de riscuri asociate pandemiei COVID-19: riscul de instabilitate economică; riscul de protecție de socială și de sănătate și riscul statutului ocupațional. Cadrul teoretic al articolului se bazează pe teoriile interdisciplinare care explică ocuparea precară, dezvoltate de Rodgers şi Rodgers (1989); Vosko, (2006) Kalleberg $(2009,2011)$ și Standing (2011). Studiile amintite analizează precaritatea în relație cu flexibilizarea și insecuritatea muncii. Analiza propusă încearcă să răspundă la două întrebări: din ce perspective critice și teoretice putem vorbi despre noi efecte ale precarizării muncii, specifice capitalismului neo-liberal, care a creat noi cerințe și strategii alternative ale ocupării digitale? Care este impactul economic și politic al pandemiei COVID-19 asupra ocupării flexibile din industria livrării, intermediate de procesul de digitalizare și la ce riscuri sunt expuși lucrătorii din această industrie? Metodologia de cercetare a articolului cuprinde o analiză descriptivă de date secundare despre evoluția ocupării flexibile și a platformelor digitale în România din EUROSTAT, INSEE, EUROFOUND, COLLEEM, susținută de o analiză critică de conținut a articolelor și rapoartelor de policy apărute recent în presa națională și internațională și care tratează riscurile și vulnerabilitățile lucrătorilor din industria livrării, care s-au aflat în linia întâi în timpul primului val al pandemiei provocate de COVID-19. Articolul conține trei părți care descriu gradual asocierea dintre precaritate, digitalizare și contextul economic și politic provocat de criza de COVID-19. Prima parte va poziționa 
teoretic precaritatea în contextul post-Fordist al studiilor sociologice asupra muncii precare, partea a doua va analiza succint ocuparea precară, de la criza economică din 2009 până la criza provocată de virusul COVID-19 în 2020, iar partea a treia se va centra pe perioada crizei COVID-19 și va avea ca studiu de caz personalul din industria livrării de produse la domiciliu, care lucrează pe platformele digitale din România.

\section{ABORDĂRI TEORETICE ASUPRA EFECTULUI DE PRECARIZARE A MUNCII FLEXIBILE}

Efectele multiple ale precarizării muncii au fost examinate în studii interdisciplinare asupra consecințelor calității vieții de muncă (Rodgers și Rodgers 1989; Quinlan, 2001; Vosko, 2006; Broughton și alții, 2010; Vallas, 2012, 2015; Kalleberg, 2009, 2011). Efectul precarizării se referă la situațiile de insecuritate economică și incertitudine cu privire la continuitatea muncii: venituri mici și insuficiente; vulnerabilitate împotriva concedierii abuzive sau lipsa de protectie socială. Pe de o parte, precaritatea a fost asociată cu formele de muncă flexibilă, cum este cazul contractelor temporare, pe durată determinată sau cu timp parțial. Aceste tipuri de contracte sunt cele mai vulnerabile la schimbările politice și economice, atât prin insecuritatea muncii, cât și a salarizării minime. Nu în ultimul rând, precaritatea a fost definită prin noi dimensiuni ale muncii care nu sunt întotdeauna vizibile, cum ar fi munca cognitivă, experiențele de epuizare profesională, problemele de echilibru dintre viața profesională și viața de familie și bolile de sănătate mintală.

La nivelul discursului academic, ocuparea precară a fost analizată prin intermediul teoriilor polarizării pieței muncii care explică precaritatea ca o consecință directă a fenomenului de flexibilizare a muncii (Rodgers și Rodgers 1989; Quinlan, 2001; Vosko, 2006; Broughton și alții, 2010; Vallas, 2012; 2015; Kalleberg, 2009, 2011). Teoria polarizării enunțate de Kalleberg $(2009 ; 2011)$ susține faptul că există locuri de muncă considerate prestigioase pentru clasa mijlocie, care sunt relativ bine plătite şi care oferă beneficii pe termen mediu și lung în raport cu stabilitatea și continuitatea locului de muncă. Polarizarea creează din ce în ce mai multe locuri de muncă precare și vulnerabile la schimbările politice și economice, în numele adaptării pe o piață a muncii flexibile și mobile (Kalleberg, 2009; 2011).

Ocuparea precară a fost considerată în literatura de specialitate un fenomen cu valențe multidimensionale (Rodgers și Rodgers 1989; Burgess și Campbell, 1998; Quinlan, 2001; Vosko, 2006; Standing, 2011). Ca fenomen multidimensional, prin ocuparea precară se pot distinge câteva caracteristici: instabilitatea și insecuritatea locului muncă; insecuritatea remunerației; insecuritatea și lipsa de control asupra timpului de lucru; insecuritatea acumulării unei experiențe profesionale pe termen 
lung; insecuritatea la nivelul reprezentării colective a angajaţilor (Rodgers și Rodgers 1989; Vosko, 2006; Chan și Tweedie, 2015). Alte studii sociologice au arătat faptul că riscurile muncii precare coincid cu punctele cruciale din cursul de viață al lucrătorilor și afectează capacitatea indivizilor de a lua decizii pe termen lung, prin asumarea unei vieți independente sau prin amânarea unor decizii de a întemeia o familie (Chan și Tweedie, 2015). Vulnerabilitățile sociale ale muncii precare prezintă consecințe asupra calității vieții indivizilor, atât prin lipsa de stabilitate profesională și financiară, cât și prin posibilitățile reduse de promovare în carieră și de reușită profesională. Analizele efectuate asupra efectului precarizării iau în considerare elementele structurale ale traiectoriilor profesionale ale indivizilor, acestea incluzând mecanismele care țin de mobilitatea pe piața muncii, tipul și durata contractelor de muncă sau de stabilitatea veniturilor în fața schimbărilor economice și politice (della Porta, 2015). Cu toate acestea, studierea precarităţii din perspectiva percepțiilor indivizilor care experimentează riscuri și incertitudini cu privirea la viața de muncă a fost mult mai puțin în atenția sociologilor (Bozzon și alții, 2017; Murgia și alții, 2018). De aceea, se poate remarca faptul că studiile asupra transformărilor recente ale muncii în relație cu flexibilizarea și digitalizarea s-au concentrat pe indicatorii economici şi politici la nivel macro-social (Rodgers şi Rodgers 1989; Burgess și Campbell, 1998; Quinlan, 2001; Vosko, 2006; Standing, 2011; Pesole și alții, 2018) și mai puțin pe contradicțiile cu privire la deciziile individuale de carieră sau asupra unor aspecte importante ale vieții profesionale și sociale (Murgia, 2012).

Ocuparea precară a mai fost analizată prin teza „normalizării insecurității muncii”, care a contribuit la apariția unei noi structuri de clasă căreia îi lipsește o identitate ocupațională stabilă (Standing, 2011). Noua structură de clasă numită precariatul - experimentează insecuritatea locului de muncă, blocarea unor oportunități profesionale sau lipsa unei remunerații stabile în timp. Precariatul ca nouă clasă socială dedică în mod constant $\mathrm{o}$,muncă pentru muncă” adică o muncă neremunerată și consumatoare de timp care converge înspre necesitatea mobilității sociale pentru muncă. Mobilitatea include înregistrarea la agenții temporare, așteptarea înscrierilor, completarea formularelor, internshipuri, trimiterea de CV-uri și crearea de rețele profesionale (Standing, 2011). Conform lui Standing (2011), precariatul este iminent pentru oricare lucrător, fie că e vorba despre căderea în capcana ,insecurității flexibile - ca formă de muncă alternativă” - fie prin considerarea locului de muncă actual o punte de lansare spre un loc de muncă mai stabil, în conformitate cu experiența profesională (Standing, 2011: 59).

$\mathrm{Nu}$ în ultimul rând, munca precară este analizată prin intermediul muncii involuntare, non-tradiţionale, instabile în timp, cu locuri de muncă de slabă calitate, care implică riscuri şi care aduce sărăcie pe termen lung (Tucker, 2002). În continuare, vom prezenta succint situația de criză a ocupării din România, în asocierea cu flexibilizarea și digitalizarea, înainte de pandemia provocată de COVID-19. 


\section{SCURT PREAMBUL ASUPRA SITUAȚIEI DE CRIZĂ DE PE PIAȚA MUNCII DIN ROMÂNIA}

\section{Precaritatea ocupării și politica salariului minim înainte de pandemia COVID-19}

România se confrunta și înainte de criza pandemiei provocate de COVID-19 cu un grad de ocupare precară, caracterizată prin venituri modeste şi fluctuante, la limita sărăciei. Gradul de salarizare și securitatea locului de muncă reprezintă un indicator fundamental al calității vieții de muncă. În România, ocuparea e foarte diversificată calitativ: "indicatorul cel mai relevant pentru gradul de participare la o activitate economică capabilă să asigure un standard de viață decent este proporţia de salariați din populația activă" (Zamfir, 2015: 22).

Flexibilizarea ocupării prezintă avantaje pentru stimularea economică, precum și pentru asigurarea mobilității pe piața muncii din România și la nivel european. Efectele pozitive s-ar putea reflecta în scăderea ratei șomajului și în faptul că mulți salariați ar putea să prefere un loc de muncă temporar sau cu timp parțial pentru a dispune de flexibilitatea timpului liber sau a locului de muncă, sau pentru o mai bună reconciliere a vieții de familie cu viața profesională.

Prin asocierea directă cu perioada post-Fordistă, transformările din ultimul deceniu ale legislației muncii și dialogului social au venit cu noi cerințe ale ocupării care au favorizat flexibilizarea (Harvey, 2005; Kalleberg, 2009; Trif, 2013; Ban, 2016). O parte dintre schimbările care au avut loc în ultimul deceniu în structura profesională din România au fost provocate de consecințe directe ale adoptării Codului muncii din 2003 și amendamentelor ulterioare, dar și prin apariția unor noi oferte de muncă intermediate de procesul digitalizării platformelor de muncă la distanță (Pesole și alții, 2018; Brancati, 2020). Cerințele noi au însemnat îndepărtarea treptată de formele de muncă așa numite „tradiționale”, prin lărgirea și extinderea unor contracte flexibile și mai dinamice, care să răspundă în același timp unei piețe a muncii mobile și digitale.

În ciuda unor avantaje economice, flexibilizarea scade posibilitatea lucrătorilor de a avea un contract permanent și cauzează fragmentarea în locuri de muncă precare. Munca flexibilă este considerată precară din cauza veniturilor mici și instabilităţii ocupării pe perioade lungi de timp. La o privire mai atentă asupra datelor EUROSTAT (2018), observăm că lucrătorii cu contracte de muncă temporară au crescut de la $11 \%$ în 2002 la 13\% în 2017. Cele mai mari procente ale contractelor temporare de muncă se găseau în Polonia și Spania, cu 26\% și cele mai mici în România, cu 1\%.

România nu urmează curentul european în ceea ce privește creșterea contractelor cu timp parțial, care este la nivelul UE de $19 \%$, cel mai mare procent fiind înregistrat de Olanda cu 47\%. În ceea ce-i privește pe lucrătorii pe cont propriu dependenți (adică, lucrătorii pe cont propriu care se găsesc într-o situație de dependență față de angajatori), datele nu sunt însă atât de clare. Ponderea lucrătorilor 
pe cont propriu la nivelul INSEE rămâne în continuare foarte ridicată, acest lucru fiind valabil chiar și pentru sectoarele neagricole, acolo unde nu intră munca zilieră. Așadar, ponderea lucrătorilor pe cont propriu (PFA-uri, drepturi de autor, contracte de prestări servicii, zilieri) este mai mare în prezent decât în anii anteriori crizei economice din 2008.

Tabelul nr. 1

Rata ocupării în România, comparativ cu UE28 și UE15, 2018

(în procente din totalul ocupării/ persoane active 15-64 ani)

\begin{tabular}{|l|c|c|c|c|c|c|c|c|}
\hline & \multicolumn{2}{|c|}{$\begin{array}{c}\text { Rata totală a } \\
\text { ocupării }\end{array}$} & \multicolumn{2}{c|}{$\begin{array}{c}\text { Ocuparea } \\
\text { temporară }\end{array}$} & \multicolumn{2}{c|}{ Timp parțial } & \multicolumn{2}{c|}{$\begin{array}{c}\text { Rata neocupării } \\
\text { persoanelor active }\end{array}$} \\
\hline & bărbați & femei & bărbați & femei & bărbați & femei & bărbați & femei \\
\hline UE28 & 73,8 & 63,3 & 11,2 & 13,1 & 8,7 & 31,3 & 6,6 & 7,1 \\
\hline UE15 (1995-2014) & 73,7 & 63,7 & 11,7 & 13,5 & 9,9 & 37,0 & 7,9 & 8,8 \\
\hline România & $\mathbf{7 3 , 2}$ & $\mathbf{5 6 , 2}$ & $\mathbf{0 , 9}$ & $\mathbf{0 , 7}$ & $\mathbf{6 , 2}$ & $\mathbf{6 , 9}$ & $\mathbf{4 , 7}$ & $\mathbf{3 , 5}$ \\
\hline
\end{tabular}

Sursa: Eurostat, [une_rt_a] [lfsa_ergan] [lfsi_pt_a].

Conform datelor disponibile la INSEE și EUROSTAT, în România, ocuparea cu contract de muncă cu normă parțială reprezintă un fenomen mai izolat și mai puțin dinamic în evoluția contractelor de muncă, după 1990. România prezintă o situație diferită de celelalte țări europene: un procent scăzut de lucrători cu contracte temporare $(0,9 \%$ bărbați și $0,7 \%$ femei) și cu contracte cu timp parțial $(6,2 \%$ bărbați şi $6,9 \%$ femei).

În prezent, dincolo de evoluția contractelor flexibile, transformările muncii la nivel național, prin alinierea la standardele Uniunii Europene și la o piața a muncii competitive au adus pe agenda publică subiecte precum impactul creșterii salariului minim în relație cu contractele de muncă flexibilă. În 2018 , se estima că $46 \%$ dintre contractele de muncă sunt remunerate la nivelul salariului minim, iar majoritatea dintre acestea se regăseau în mediul privat. Problema contractelor remunerate la nivelul salariului minim ne trimit la o dezbatere relevantă asupra deghizării economiei gri, care este în continuare ignorată la nivel politic, iar cuantificarea acestor cifre la nivelul statisticilor naționale este cvasi-inexistentă (Piarom, 2018).

România a prezentat cele mai mari creșteri din UE în ceea ce privește salariul minim brut. În februarie 2017, salariul minim a fost crescut de la 1250 la 1450 lei brut, iar în ianuarie 2018 a crescut din nou, până la 1900 de lei brut, iar în 2019 ajungea la 2350 lei brut. Creșterea salariului minim nu este corelată cu tipul de contract, cu ramurile industriale, cu pregătirea profesională sau cu vechimea în muncă. Inegalitățile dintre salariaţi sunt evidente mai ales în cazul persoanelor care ocupă posturi care necesită pregătire profesională și pentru care creșterea salariului minim nu influențează în mod direct ritmul de muncă sau productivitatea muncii. Salariile mici distribuite ca urmare a creșterii flexibilizării forței de muncă au fost o urmare a crizei economice, dar și o cerință europeană de a relaxa programul de muncă și condițiile de muncă. La nivel politicilor de ocupare, spre exemplu, legea 
dialogului social nu a sprijinit spre negociere salariații remuneraţi la salariul minim, ci a redus drepturile colective ale salariaților, înclinând astfel balanța în favoarea angajatorilor, îndeosebi în cazul lucrătorilor din mediul privat. Dacă în 2011 se regăseau, conform datelor de la Inspecția Muncii, în jur de 450000 de contracte de muncă remunerate la nivelul salariului minim, numărul a crescut la aproape 2,8 milioane, aproximativ $46 \%$ din total contractelor de muncă înregistrate în anul 2017 (Piarom, 2018; Guga, 2018).

\section{Privire generală asupra ocupării pe platformele digitale în România}

În ultimul deceniu de la declanşarea crizei economice am asistat la o diversificare a muncii, îndeosebi prin apariția unor noi oferte de muncă intermediate de digitalizare. Flexibilizarea muncii și diversificarea relațiilor contractuale intermediate de automatizare și digitalizare au condus, invariabil, la noi oportunități de muncă, dar și la crearea unor noi tipuri de vulnerabilităţi și noi riscuri asociate cu întreruperile recurente în organizarea și contractarea muncii. Comisia Europeană a elaborat în perioada 2016-2019 o serie de rapoarte de politică publică referitoare la noile tipuri de muncă intermediată digitală, care poartă denumirea de ,economie colaborativă” o noțiune care include forța de muncă furnizată prin sau mediată de platformele online pe câteva sectoare economice (Pesole și alții, 2018). Această agendă europeană acceptată în România în anul 2017 este destinată orientării juridice și politice, în vederea contribuirii la asigurarea unei dezvoltări echilibrate a economiei colaborative și pentru monitorizarea evoluției economice intermediate de platformele online. În agenda pentru economia colaborativă este subliniată contribuția semnificativă pentru creșterea gradului de inovare în organizarea muncii, accentul fiind orientat către asigurarea unor condiții de muncă echitabile, fără discriminare socială sau rasială și cu o protecție socială crescută în rândul lucrătorilor.

Munca intermediată de platformele digitale se regăsește în forme variate, iar conform Eurofound (2018), principalele caracteristici ale muncii intermediate de platforme sunt următoarele:

- Munca plătită este organizată printr-o platformă online.

- Sunt implicate trei părți: platforma online, clientul și lucrătorul.

- Scopul muncii este îndeplinirea unor sarcini specifice sau rezolvarea de probleme specifice.

- Lucrările sunt subcontractate sau contractate.

- Locurile de muncă sunt defalcate pe sarcini.

- Serviciile sunt furnizate la cerere.

Tendința digitalizării ocupării prin extinderea noilor tipuri de muncă digitală au sporit flexibilitatea muncii în România. Fenomenul ocupării intermediate de apariția platformelor digitale în România este recent. Deși nu există o legislație specifică pentru reglementarea acestui tip de muncă, România este luată ca studiu 
de caz în multe rapoarte de recomandare politică realizate la nivel european (Eurofound, 2018; COLLEEM, 2018; 2020).

Pe lângă documentele de politică publică în care se pune accentul pe o situație favorabilă diversificării condițiilor de muncă prin intermediul platformelor digitale, în continuare la nivelul statelor membre ale Uniunii Europene şi la nivelul României, statutul profesional al persoanelor care lucrează prin intermediul platformelor online nu este unitar și clar reglementat. Statutul ocupațional este dictat atât de legislația muncii în vigoare la nivel european și la nivelul țărilor membre, cât și prin termenii legali impuși de platformele digitale, ceea ce rezultă într-o relație inegală de negociere între angajatori și lucrători.

Estimările legate de rata ocupării prin platforme digitale în România arată că majoritatea lucrătorilor lucrează în industria de transport și industria alimentară sau livrări de mărfuri. O categorie aparte este reprezentată de sectorul IT, o categorie de lucrători de înaltă calificare, care prestează servicii prin intermediul platformelor, dar care nu este expusă riscurilor economice.

Totuşi, comparativ cu țările UE, România este într-o etapă incipientă a dezvoltării economiei digitale, platformele internaționale deținând o cotă de piaţă mult mai mare, în comparaţie cu platformele interne care operează exclusiv la nivel național (EC, 2018). Conform studiului COLLEEM (2018), estimările cu privire la numărul de persoane angajate pe platforme online arată faptul că România are cel mai mic procent din țările UE.

Grafic 1

Rata ocupării pe platforme digitale în țările UE (studiul COLLEEM)

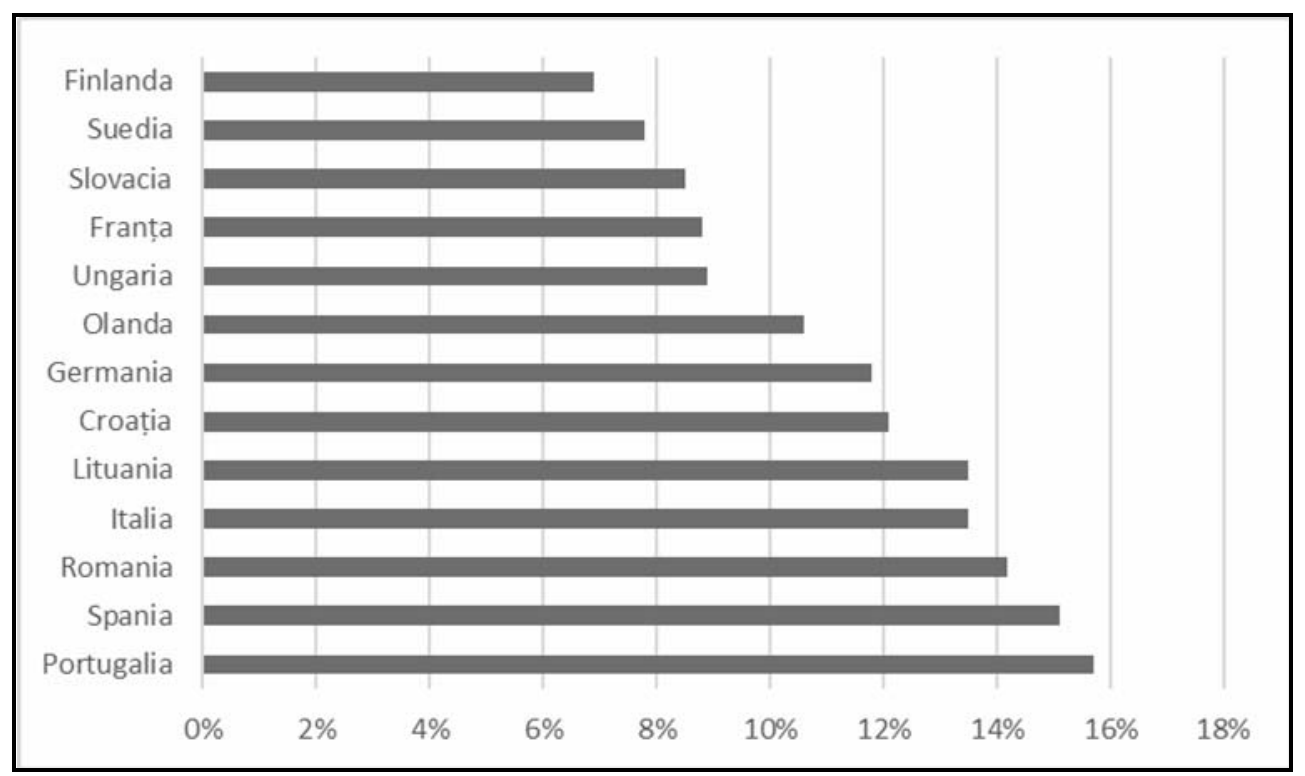

Sursa: COLLEEM survey, estimări, Pesole și alții, 2018. 
Conform acestui studiu, România are şi cel mai mare risc de dezvoltare a muncii slab calificate din toate țările UE. Același studiu menționează faptul că în România munca intermediată digital este supraevaluată ca favorizând flexibilitatea în organizarea muncii. La nivel european, gradul de dezvoltare a economiei colaborative prin munca intermediată digital variază semnificativ. Cea mai mică influență a acestor forme de muncă este în: Polonia (0,64\%), Letonia $(0,63 \%)$, Luxemburg $(0,44 \%)$, Republica Cehă $(0,44 \%)$ și Suedia $(0,29 \%)$. Ponderea medie din economia colaborativă în economia totală este calculată la $0,2 \%$, la nivelul UE-28 (Pesole și alții, 2018).

Cercetarea COLLEEM a investigat munca pe platforme digitale în 14 țări din Europa. Pentru estimarea numărului de lucrători de pe platformele digitale, a fost pusă întrebarea dacă respondenții au avut venituri din diverse surse online. Sursele online erau: ,a furniza servicii prin platformele online, prin implicarea unei relații dintre client și furnizor, iar plata se face online” sau „furnizarea de servicii prin intermediul unei platforme online, plata se efectuează digital dar munca se realizează la locația clientului”. Graficul 1 conține date estimate despre respondenții care au răspuns pozitiv la una dintre opțiunile muncii pe platforme, calculat ca procent din totalul cazurilor investigate în acest sondaj. În 2017, numărul de persoane estimate ca lucrând pe platformele digitale în România era de 6253 de persoane. Din această perspectivă, România prezintă rata cea mai mică a ocupării prin platforme digitale din UE. Totuși, aşa cum vom prezenta în continuare, este de aşteptat ca rata ocupării pe platformele digitale să crească foarte mult în perioada pandemiei COVID-19, cât și după această perioadă de vârf, ca urmare a extinderii platformelor digitale de livrare, dar și datorită tele-muncii.

\section{CONTEXTUL OCUPĂRII ÎN TIMPUL PANDEMIEI COVID-19}

Cifrele prezentate de Ministerul Muncii și Protecției sociale arătau o evoluție îngrijorătoare în ceea ce privește dinamica contractelor de muncă suspendate și încetate, de la declanșarea situației de urgență provocată de COVID-19. Conform datelor centralizate la data de 11 mai 2020, aproximativ $22 \%{ }^{23}$ (1 245939 de contracte de muncă la data de 11 mai 2020 estimate dintr-un total de 4820136 de contracte de muncă cu normă întreagă/ perioadă nedeterminată) dintre contractele de muncă din România au fost suspendate sau încetate, începând cu data de 14 martie 2020. Deși este devreme pentru a estima impactul economic pe care criza COVID-19

${ }^{23}$ Estimarea realizată pornind de la datele furnizate de Inspecția Muncii în ceea ce privește numărul contractelor de muncă din România. O persoană poate avea unul sau mai multe contracte de muncă concomitente, ceea ce înseamnă că estimarea statistică se referă strict la numărul de contracte afectate de criza COVID-19 și nu la numărul de persoane ale căror contracte au fost suspendate sau care au încetat ca urmare a crizei. INSEE nu adună date despre numărul contractelor de muncă, ci doar despre populația ocupată (în număr de persoane). Singurele instituții din România care au o evidență asupra contractelor de muncă sunt: Inspecția muncii și Inspectoratele teritoriale de muncă. 
o are asupra pieței muncii și asupra ofertelor de locuri de muncă disponibile în perioada următoare, conform informațiilor disponibile cele mai afectate ramuri ale economiei naționale au fost următoarele: industria prelucrătoare; comerț cu ridicata şi cu amănuntul, repararea autovehiculelor și motocicletelor; hoteluri și restaurante; constructii. În cadrul acestor ramuri de activitate ale economiei naționale, conform unui studiu despre salariații remunerați la salariului minim (Ciucă și alții, 2016), în 2015 se regăseau cele mai multe firme cu salariați vulnerabili care erau remuneraţi la nivelul salariului minim brut pe țară. Este de așteptat ca veniturile salariaților să scadă substanțial în perioada pandemiei, iar insecuritatea economică să afecteze deciziile de viață și de carieră.

Grafic 2

\section{Numărul contractelor de muncă cu normă întreagă suspendate şi încetate (mai 2020) versus numărul total de contracte de muncă (2018)}

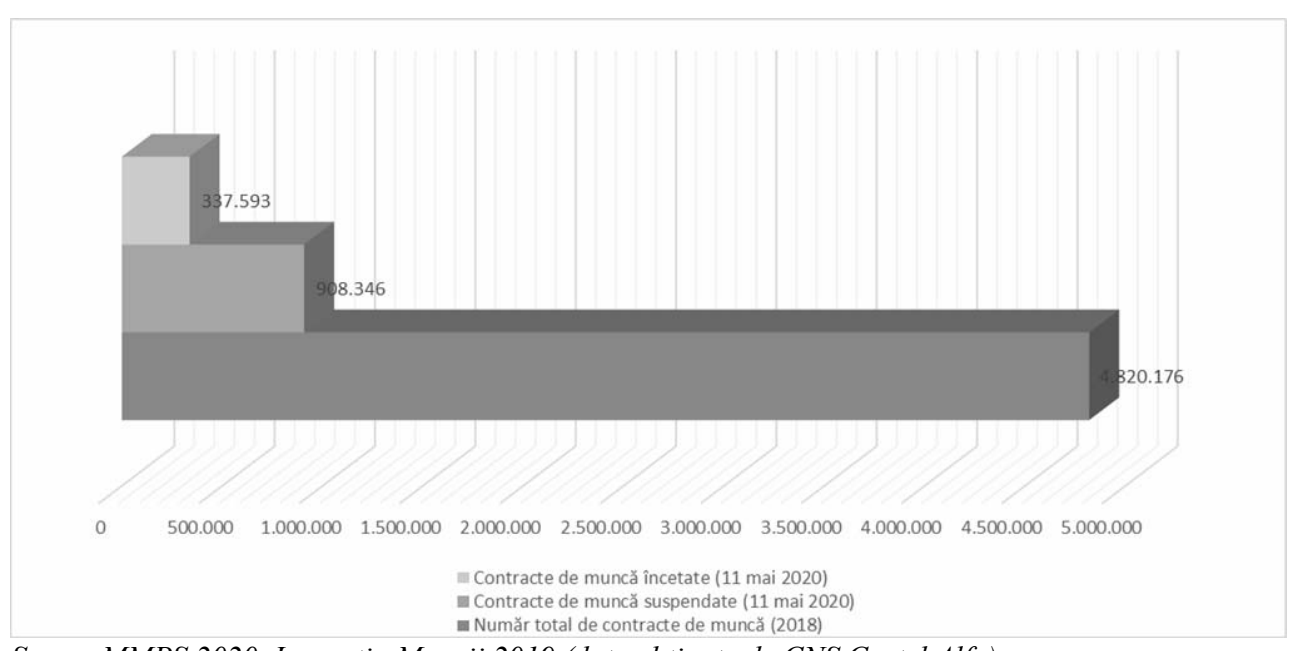

Sursa: MMPS 2020, Inspecția Muncii 2019 (date obținute de CNS Cartel Alfa).

Pe baza estimărilor legate de salarizarea din ramurile de activitate puternic afectate de criza COVID-19, trimiterea în şomaj tehnic a însemnat intrarea în sărăcie a lucrătorilor din cele patru ramuri ale economiei naționale (Rev. 2) care au fost raportate până acum de MMPS. Conform ordonanțelor privind reglementarea șomajului tehnic pe perioada situației de urgență, lucrătorii ai căror contracte de muncă au fost suspendate vor beneficia de $75 \%$ din salariul de bază, ceea ce pentru lucrătorii plătiţi la salariul minim reprezintă sume care nu permit nici măcar asigurarea nevoilor de bază, conform unui calcul al coșului minim de consum din $2019^{24}$.

\footnotetext{
${ }^{24}$ Studiul FES 2018, „Coșul minim de consum lunar pentru un trai decent pentru populația României” http://library.fes.de/pdf-files/bueros/bukarest/14759.pdf.
} 
Graficele 3 și 4

Numărul de contracte de muncă încetate și suspendate (mai 2020)

pe ramuri ale economiei naționale

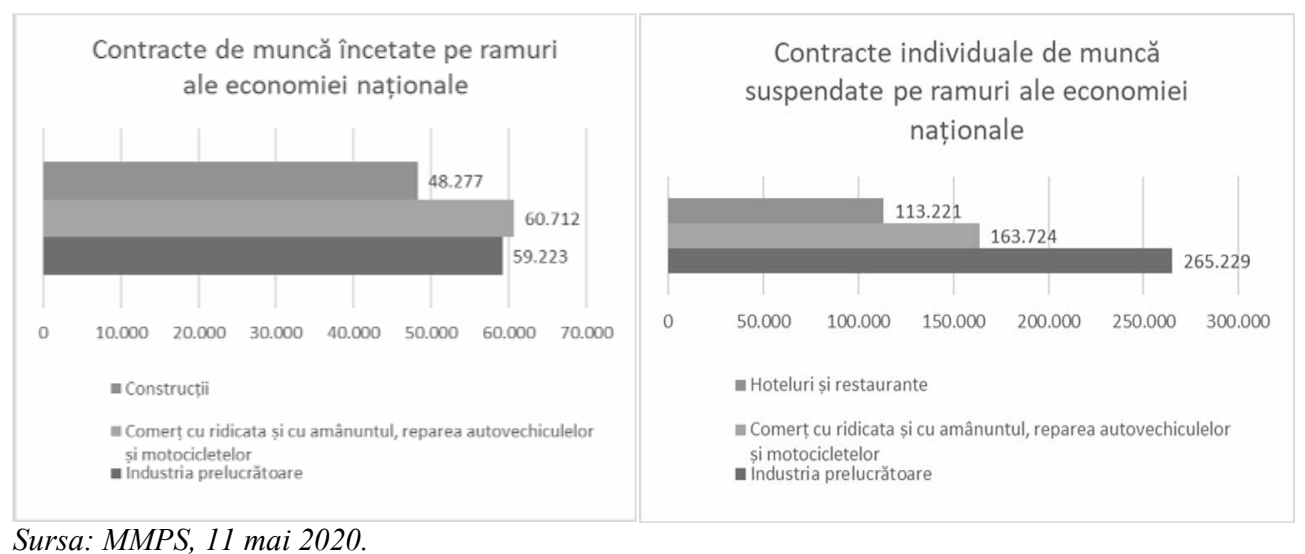

\section{Cazul particular al muncii de livrare la domiciliu în perioada crizei COVID-19}

În contextul social creat de pandemia COVID-19 în România, se poate discuta despre stabilirea unei agende digitale a pieței muncii, favorizată în special de oferta de locuri de muncă disponibilă prin platformele digitale de livrare de produse la domiciliu. Conform datelor furnizate de firmele din România care intermediază munca lucrătorilor din industria de livrare a produselor, pentru o mare parte dintre acestea (vezi Tabelul nr. 2) criza provocată de COVID-19 a însemnat oportunitatea de a se dezvolta din punctul de vedere economic. În timp ce sectoarele economice puternic afectate de instaurarea măsurilor pentru situația de urgență își opreau definitv sau suspendau temporar activitatea (conform Graficelor 3 și 4), sectorul reprezentat de livrarea de produse alimentare și non-alimentare la domiciliu a cunoscut o dezvoltare prin extinderea geografică a unor activităti online de livrare, dar și prin diversificarea și reprofilarea pe sectoare economice menite să sprijine desfășurarea activităților de livrare a ramurilor economice puternic afectate de criza COVID-19.

Platformele digitale, cum este Uber (România), Deliveroo (Germania, Belgia, Franța), Food Panda (România), Glovo (România) și-au putut extinde cu mare ușurință oferta de forță de muncă, datorită cererii foarte mari de servicii de livrare la domiciliu pe perioada pandemiei. La nivel european, conform Altenried și colab. 2020, în Marea Britanie platformele Uber, Deliveroo și Just Eat (care aparține platformei Takeaway.com) au încheiat contracte de colaborare cu guvernul britanic pentru furnizarea de bunuri zilnice de primă necesitate pentru vârstnici. Același studiu estimează faptul că platforma Deliveroo a reușit într-un timp relativ scurt să-și dubleze profitul prin colaborările cu marile lanțuri de supermarket. Alte mari 
companii, cum e cazul Amazon, au profitat de cererea crescută de livrări la domiciliu și au crescut oferta de forță de muncă în depozitele fizice și au anunțat noi angajări și salarii crescute, în contextul riscului de infectare cu COVID-19 (Altenried și colab. 2020).

Conform statisticii lunare publicate de Anunţul.ro ${ }^{25}$, în România a existat o cerere crescută de curieri de produse alimentare la domiciliu în perioada martieaprilie 2020 și o scădere semnificativă la oferta de locuri de muncă care înainte de criză ocupau topul cererii de forță de muncă: baby-sitting, personal de serviciu de curățenie, ospătari sau barmani. Conform unei analize rapide de conținut asupra ofertei de forță de muncă pe perioada pandemiei, cele mai căutate și vizualizate oferte de muncă în luna martie au fost: livratori de pizza cu jumătate de normă; şofer distribuție produse alimentare; livratori pizza cu normă întreagă. Salariile pentru aceste locuri de muncă erau estimate de la 2500 lei la 3000 lei pe lună. La o privire atentă asupra ofertelor de muncă disponibile în domeniul livrării în perioada mai-iunie 2020 se constată faptul că oferta de locuri de muncă a scăzut substanțial, platforma Glovo România anunțând că începând cu luna mai 2020 nu mai face angajări.

Industria livrării online de produse poate fi analiză în condițiile actuale ale organizării muncii la distanță ca o alternativă pe piața muncii care a fost puternic lovită de șomaj și de disponibilizări pe sectoarele de activitate ale căror activități au fost suspendate în perioada pandemiei. Pentru o parte din populația ocupată afectată de pandemie, care a intrat în șomaj tehnic sau care și-a pierdut locul de muncă, platformele online de livrare au devenit o nouă sursă temporară de venit. Așadar, în continuare vom prezenta câteva cazuri ale celor mai mari platforme digitale de livrare la domiciliu din România prin care acestea și-au extins activitatea economică pe perioada pandemiei COVID-19.

În plină criză economică cauzată de pandemie, platforma de livrare online Glovo şi-a extins activitatea în alte orașe din România, printre care Slatina și Buzău. Serviciul online Glovo este realizat de către curieri independenți care se înscriu în aplicație și care sunt plătiţi la oră, conform unui algoritm matematic care calculează numărul de livrări la timpul petrecut efectiv în aplicație. Serviciul de livrare permite atât comenzi rapide de mâncare, produse alimentare cât și pentru trimiterea sau expedierea de pachete, documente, plicuri sau diverse obiecte cumpărate sau trimise de diverse persoane. Serviciile online pentru livrări au pătruns în România începând cu anul 2018 și s-au extins până astăzi în mare parte a orașelor din România: București, Cluj-Napoca, Timișoara, Iași, Brașov, Craiova, Constanța, Sibiu, Arad, Ploiești, Brăila, Galați, Oradea, Pitești, Buzău și Slatina. Pe lângă platforma Glovo, recent, de la izbucnirea crizei COVID-19, alte platforme digitale au anunțat transformarea domeniului principal de activitate în servicii

${ }^{25}$ Conform analizei disponibile aici: https://economie.hotnews.ro/stiri-imobiliar-23772548anunturi-bucuresti-vremea-covid-ului-cauta-livratori-domiciliu-scad-chiriile-preturile-caselor-rezista. htm. 
destinate livrării de produse, cum este cazul platformelor de ridesharing Bolt, Yango sau Uber. Pe fondul lipsei cererii de transport și ridesharing, platformele și-au extins activitatea principală cu activitatea de livrare de produse la domiciliu.

Extinderea platformelor digitale de livrări are loc cu o mare rapiditate. Din 2018 până în prezent în România existau peste șapte platforme, printre care: Glovo, Uber Eats (care și-a încetat activitatea în iunie 2020), Food Panda, Hipmenu, Caserola.ro, Takeaway, Bringo. Tabelul de mai jos prezintă succint cum s-au transformat principalele platforme digitale pe timpul pandemiei COVID-19.

Tabelul $n r .2$

Dezvoltarea platformelor digitale de livrare în perioada pandemiei COVID-19

\begin{tabular}{|l|l|l|}
\hline $\begin{array}{l}\text { Platformă digitală } \\
\text { de livrare produse } \\
\text { la domiciliu }\end{array}$ & \multicolumn{1}{|c|}{$\begin{array}{c}\text { Activități economice extinse în perioada } \\
\text { pandemiei COVID-19 }\end{array}$} & Riscuri asociate \\
\hline UBER (transport) & $\begin{array}{l}\text { Transformarea servicii de taximetrie în servicii de } \\
\text { livrare, şoferii independenți livrează produse la } \\
\text { domiciliu. }\end{array}$ & $\begin{array}{l}\text { Riscuri de sănătate și } \\
\text { protecție socială }\end{array}$ \\
\hline GLOVO & $\begin{array}{l}\text { Extinderea geografică și diversificarea tipurilor } \\
\text { de produse care pot fi livrare: produse medicale, } \\
\text { medicamente, servicii tip poștă - livrare plicuri, } \\
\text { documente oficiale etc., servicii la domiciliu prin } \\
\text { livrarea de produse de la serviciu - acasă, între } \\
\text { mai multe rezidențe etc. }\end{array}$ & $\begin{array}{l}\text { Riscuri de protecție } \\
\text { socială; instabilitate } \\
\text { economică; statut } \\
\text { ocupațional incert }\end{array}$ \\
\hline FOOD PANDA & $\begin{array}{l}\text { Extinderea spre servicii de marketing și } \\
\text { consultanță pentru restaurantele care și-au închis } \\
\text { activitatea în vederea livrării de mâncare. }\end{array}$ & $\begin{array}{l}\text { Riscuri de instabilitate } \\
\text { economică și statut } \\
\text { ocupațional incert }\end{array}$ \\
\hline BOLT & $\begin{array}{l}\text { Reprofilarea platformei digitale spre activități de } \\
\text { livrare de produse alimentare la domiciliu. }\end{array}$ & $\begin{array}{l}\text { Riscuri de sănătate și } \\
\text { protecție socială }\end{array}$ \\
\hline eMAG & $\begin{array}{l}\text { Achiziția platformei de livrare de produse } \\
\text { alimentare Tazz by eMAG; } \\
\text { Extinderea platformei Sameday către noi servicii } \\
\text { livrare la domiciliu „Livrare fără griji”. }\end{array}$ & $\begin{array}{l}\text { Riscuri de sănătate și } \\
\text { protecție socială }\end{array}$ \\
\hline $\begin{array}{l}\text { Bringo (aplicație de } \\
\text { livrare deținută de } \\
\text { Carrefour) }\end{array}$ & $\begin{array}{l}\text { Extinderea serviciilor de livrare la domiciliu } \\
\text { printr-un parteneriat cu Blackcab. }\end{array}$ & $\begin{array}{l}\text { Riscuri de sănătate și } \\
\text { protecție socială }\end{array}$ \\
\hline
\end{tabular}

Riscuri asociate muncii de livrare în timpul pandemiei COVID-19

\section{Protecția socială și de sănătate}

Munca pe platformele de livrare nu reprezintă propriu-zis o formă de ocupare standard. $\mathrm{O}$ parte dintre lucrători sunt pe cont propriu și se înscriu pe platforma doar pentru a avea o formă suplimentară de venit. Perioada crizei a favorizat apariția acestor mini-joburi temporare în industria livrării, extrem de precare, cu contracte cu timp parțial, intermediate de o aplicație (numită platformă digitală) și 
plătite la oră și în funcție de comenzile primite în aplicație. Curierii reprezintă una dintre categoriile cele mai vulnerabile de lucrători, care sunt expuși direct la riscurile infectării cu COVID-19, pentru că lucrează în linia întâi, prin contactul recurent cu clienți și nu au echipament de protecție. Platformele din România nu sunt responsabile de oferirea de echipamente de protecție în fața expunerii la virusul COVID-19 și legal, nu sunt obligate să ofere asigurare medicală în caz de îmbolnăvire sau în caz de accidente.

Personalul de livrare ocupă preponderent o poziție precară pe piața muncii din cauza veniturilor scăzute și fragmentate, unde accesul la protecție socială și la urgențe medicale nu este asigurat pe perioada pandemiei. În multe țări europene, printre care Germania și Marea Britanie, lucrătorii pe platformele de livrare sunt majoritatea imigranți, cu situații sociale care nu le permit să renunțe la munca de livrare în perioada pandemiei COVID-19 (Altenried și alții, 2020).

Legislaţia muncii din România este neclară cu privire la drepturile individuale de protecție socială a lucrătorilor, îndeosebi pentru lucrătorii pe cont propriu. Accesul statutar la schema de protecție socială pentru lucrătorii pe cont propriu care lucrează pe platformele online nu este automat inclus în Codul Muncii. Toate celelalte taxe şi impozite, inclusiv asigurarea obligatorie de sănătate, asigurarea șomajului, pensiile și alte obligații sunt în continuare în responsabilitatea lucrătorului independent, în conformitate cu obligațiile fiscale prevăzute în Codul fiscal, Legea nr. 227/2015. În alte cazuri, unde lucrătorii au contracte de muncă, obligațiile sunt transferate către firma intermediară, unde persoana este angajată temporar, cu contract de muncă.

\section{Statutul ocupațional incert}

Pentru a înțelege de ce personalul de livrare este expus riscurilor de sănătate și de protecție socială, trebuie să ne uităm mai aproape la avantajele oferite de statutul ocupaţional al acestei categorii de lucrători. Conform legislației muncii în vigoare, în Codul Muncii (Legea nr. 53/2003) nu există definiții clare pentru organizarea muncii pentru categoria profesională de lucrători care desfăşoară activități specifice pe platforme digitale. Câteva noi reglementări în domeniul ocupării au venit în completarea versiunii actuale a Codului Muncii, cum este cazul Legii tele-muncii nr. 81/2018 care se aplică pentru organizarea condiţiilor de muncă doar în cazul angajaților cu contracte de muncă (CIM), prin utilizarea tehnologiilor informației și comunicațiilor (furnizate de angajator). Alte categorii de lucrători unde livratorii pot fi încadrați din punct de vedere legal sunt: lucrători independenți (lucrător pe cont propriu cu PFA - persoană fizică autorizată / cu sau fără angajat); angajat cu contract de muncă (de obicei în cazul lucrătorului pe platformă online, contract pe durată determinată cu o companie intermediară între lucrător și platformă), sau care poate avea contract de muncă la distanță; muncitorul ocazional sau sezonier numit „zilier” (muncă plătită fără contract fix, numai cu acordul ambelor părți, de obicei pentru muncă necalificată în agricultură 
sau muncă slab calificată). Spre exemplu, la INSEE această categorie a zilierilor este trecută ca angajat pe cont propriu. În alte cazuri, categoriile lucrătorilor pe platformă se află şi la granița dintre statutul de activitate independentă și ocuparea forței de muncă cu contracte, cum este cazul unei activități pe cont propriu dependente.

Tabelul nr. 3

Încadrarea ocupațională a lucrătorilor pe platforme digitale din România

\begin{tabular}{|c|l|l|}
\hline & \multicolumn{1}{|c|}{ Statutul ocupațional } & \multicolumn{1}{c|}{ Legislația în vigoare } \\
\hline 1. & Lucrători pe cont propriu (freelance/PFA) & $\begin{array}{l}\text { Codul Muncii } \\
\text { Statut independent }\end{array}$ \\
\hline 2. & $\begin{array}{l}\text { Lucrători pe cont propriu (alte categorii freelance// } \\
\text { lucrători pe cont propriu dependenți) }\end{array}$ & $\begin{array}{l}\text { Codul fiscal/ Inspecția Muncii } \\
\text { Statut dependent }\end{array}$ \\
\hline 3. & Zilier & $\begin{array}{l}\text { Legea zilierilor (Construcții, publicitate, } \\
\text { agricultură) }\end{array}$ \\
\hline 4. & $\begin{array}{l}\text { Angajați cu contracte de muncă pe perioadă } \\
\text { determinată/ nedeterminată }\end{array}$ & Codul Muncii \\
\hline 5. & Angajați care lucrează la distanță & Legea Tele-muncii \\
\hline
\end{tabular}

Statutul profesional al lucrătorilor pe platforme digitale din România este vulnerabil și instabil deoarece legislația națională nu are reglementări clare cu privire la acest statut. În ceea ce privește dialogul social, statutul ocupațional incert împiedică majoritatea lucrătorilor, îndeosebi pe cei care au statut de lucrător pe cont propriu, să fie membri ai sindicatelor și să se solidarizeze. Conform rapoartelor Eurofound (2018), majoritatea lucrătorilor care își desfășoară activitatea pe platforme digitale nu se pot sindicaliza şi nu sunt reprezentați colectiv. Această situație este cauzată de legislația muncii și dialogului social, care la nivelul țărilor membre, nu se aplică categoriei lucrătorilor pe cont propriu. Legea privind dialogul social nu oferă o situație clară a dreptului lucrătorilor pe cont propriu să devină membri sau să fie reprezentați în mod colectiv. De asemenea, există bariere legislative care împiedică sindicatele să dețină dreptul și puterea de a recruta lucrători independenți. Legea privind dialogul social (2011) prevede la art. 3 că numai ,persoanele încadrate cu contract individual de muncă, funcționarii publici şi funcționarii publici cu statut special în condițiile legii, membrii cooperatori și agricultorii încadrați în muncă au dreptul, fără nicio îngrădire sau autorizare prealabilă, să constituie și/sau să adere la un sindicat”. Reformele structurale implementate după criza economică din România în 2009 au destructurat cadrul legislativ care reglementa și proteja piaţa muncii și au condus la o precarizare rapidă a muncii, cu precădere pe dimensiunile legate de protecția socială și colectivă a lucrătorilor.

Poziția precară a lucrătorilor de platformă care sunt lucrători pe cont propriu sau care sunt angajaţi cu contracte flexibile tinde să fie afectată de lipsa unei protecții sociale și a posibilității de organizare colectivă. Prin urmare, protejarea 
drepturilor și intereselor livratorilor, prin intermediul dialogului social adecvat categoriei lor ocupaționale, este primul pas către asigurarea unor condiții decente de muncă.

\section{Instabilitatea economică}

Pentru personalul a căror muncă de livrare este singura sursă de venit pe perioada pandemiei, riscurile insecurităţii legate de un venit insuficient şi de continuitatea muncii reprezintă principalele cauze în ceea ce privește ocuparea precară și riscul de sărăcie în muncă. Veniturile obținute din activitățile muncii pe platforme sunt variabile și foarte fragmentate în timp. Munca este remunerată în funcție de performanțele lucrătorilor și este, de cele mai multe ori stabilită, prin algoritmi matematici de către platforma care intermediază munca și nu prin negocierea legală a tarifelor orare împreună cu lucrătorii. Recent, în data de 21 aprilie $^{26}$, ca urmare a extinderii geografice a platformei digitale Glovo în România, compania a decis să uniformizeze plata bonus-urilor aferente comenzilor preluate de lucrători pentru toate localitățile în care s-a extins și drept urmare, a decis să scadă cuantumul aferent plăţii lucrătorilor. Acest lucru a stârnit greve spontane ale lucrătorilor care s-au arătat nemulțumiți de deciziile platformei de a micșora plata bonus-urilor câștigate de lucrători.

În lipsa unei reglementări clare a muncii digitale la nivelul legislației naționale în domeniul muncii, aspectele legate de protecția socială și securitatea muncii conduc la multe semne de întrebare în rândul lucrătorilor, și implicit, la o precarizare treptată a ocupării în aceste sectoare de activitate intermediate de tehnologie.

\section{CONCLUZII}

În România, deoarece digitalizarea muncii prin intermediul platformelor digitale este un fenomen relativ recent, este necesară o armonizare a legislației muncii la nivelul UE și României, pentru a colabora pentru protejarea drepturilor de muncă ale acestor lucrători. Noul tip de economie digitală se extinde în diverse activități economice, cum este cazul sectorului de servicii din România, acesta fiind cel mai extins din punct de vedere al forței de muncă și care se adaptează în momentul actual al digitalizării și al tehnologiei.

După cum arată Eurofound (2018), munca intermediată de platformele digitale este considerată flexibilă și autonomă, cu valori ridicate pentru motivația intrinsecă a organizării flexibile a muncii, care este un indicator major pentru recrutarea forței de muncă. În România, mulți lucrători aleg munca pe platforme

\footnotetext{
${ }^{26}$ Mai multe detalii despre greva spontană a lucrătorilor Glovo găsiți aici: https://www. stiridecluj.ro/economic/curierii-glovo-au-facut-greva-in-piata-mihai-viteazu-dupa-ce-a-fost-redus-bonusulpe-kilometru-foto-1.
} 
online pentru oportunitățile pe care le oferă, prin planuri flexibile de organizare a muncii și mobilitatea ridicată. Însă, în ciuda avantajelor oferite de organizarea flexibilă a muncii, legislația muncii este încă neclară în ceea ce privește drepturile individuale ale lucrătorilor care lucrează pentru platforme şi este nevoie de o analiză aprofundată a legislației muncii. În acest caz, o mare categorie de muncitori cu calificare medie și înaltă este în continuare condiționată de unii angajatori să functioneze prin acorduri de tip PFA sau contracte de drepturi de autor, îndeplinind în același timp o muncă dependentă de un angajator sau de un singur client. Motivul principal pentru a considera riscul și vulnerabilitatea acestui statut profesional de lucrător pe cont propriu dependent este faptul că INSEE a monitorizat până de curând numărul lucrătorilor pe cont propriu prin includerea muncii cu un nivel scăzut de calificare, cum este muncă în agricultură, considerată „muncă ocazională”, plătită la nivelul salariului minim, fără nici o schemă de protecție socială acoperită în conformitate cu legislația muncii în vigoare.

Pe perioada pandemiei COVID-19, în ciuda faptului că cererea de livrare la domiciliu a produselor alimentare și non-alimentare a crescut, ca urmare a măsurilor guvernamentale de distanțare socială și izolare, livratorii rămân unul dintre grupurile cele mai vulnerabile la expunerea în fața virusului COVID-19 și la riscurile de îmbolnăvire sau de protecție socială.

Platformele digitale care intermediază munca livratorilor și-au extins foarte mult activitatea profesională pe perioada pandemiei, însă riscurile la care sunt expuși curierii nu au fost diminuate, prin asigurarea de condiții minime de protecție în fața pandemiei COVID-19 (asigurare medicală, concediu medical plătit, asigurarea de echipamente de protecție, asigurarea mijloacelor de transport a produselor etc.).

Poziția adesea precară a lucrătorilor din platformele online de livrate tinde să fie puternic afectată, pe de o parte, de o lipsă de solidarizare și de organizare colectivă a lucrătorilor. Specificul muncii de livrare, care este fragmentată și ocazională pentru mulți lucrători, contribuie la o colaborare competitivă și ineficientă, în detrimentul drepturilor colective pentru munca decentă din acest sector de activitate. Pe de cealaltă parte, EU-OSHA (2017) a examinat implicațiile asupra securității și sănătății muncii pe platformele digitale. O parte dintre riscurile de sănătate fizică specifice muncii de livrare, cum ar fi oboseala sau problemele musculare, stresul și epuizarea sunt exacerbate de o serie de factori care sunt mai frecvenți în cadrul muncii pe platformă, cum ar fi lipsa de pregătire profesională adecvată, lipsa certificării, necunoașterea drepturilor salariale sau lipsa echipamentelor de siguranță (Eurofound, 2018). În plus, lucrătorii platformelor sunt expuşi riscurilor din cauza precarității muncii, afectate, pe de o parte, de presiunea monitorizării muncii, prin intermediul căreia sunt remunerați și a termenelor stricte prin care se desfăşoară munca de livrare.

Conform EU-OSHA (2017), care a examinat răspunsurile legislative și politicile de ocupare la nivelul economiei platformelor online și, mai precis, statutul ocupațional al lucrătorilor de platformă în mai multe state membre ale UE, nevoia 
de flexibilitate a muncii și dorința de a obține venituri suplimentare sunt principalii factori de atracție ai muncii pe platformele digitale.

Mulțumiri

Articolul este parțial finanțat prin grantul de cercetare GAR-UM-2019-XI-5.4-1, „Strategii de ocupare în contextul noilor vulnerabilități ale digitalizării” realizat cu sprijinul financiar din Fondul Recurent al Donatorilor, aflat la dispoziţia Academiei Române şi gestionat prin Fundaţia „PATRIMONIU” GAR-UM-2019

\section{REFERINȚE BIBLIOGRAFICE}

Adăscăliței, D., Muntean, A. 2018. Trade unionstrategies in theage of austerity: The Romanian public sector in comparative perspective, European Journal of Industrial Relations, 1-16, https:// doi.org/10.1177/0959680118783588.

Altenried et al. 2020. Covid-19: A Critical Moment for Platforms?, Disponibil Online la http://www. platform-mobilities.net/en/aktivitaeten?fbclid=IwAR0GEGf3tbR8x3Whr6x-fI3cssHygCikoV Zn8IkBHR0a1 arZ35sKYF5kO2I\#call-for-papers-platform-capitalism-and-the-crisis-of-socialreproduction.

Ban, C. 2016. Ruling Ideas How Global Neoliberalism Goes Local, Oxford, Oxford University Press.

Bozzon, R, Murgia, A et al. 2017. Work-lifeinterferences in theearly academic careerstages: The case of precariousresearchers in Italy. European EducationalResearch Journal, 16 (2-3), 332-351. https://doi.org/10.1177/1474904116669364.

UrzìBrancati, C., Pesole, A., Fernández-Macías, E. 2020. New evidence on platformworkers in Europe. Resultsfromthesecond COLLEEM survey, Publications Office of the European Union, Luxembourg.

Broughton, A., Biletta, I., Kullander, M. 2010. Eurofound Report, European Observatory of Working Life - Flexible forms of work: 'very atypical' contractual arrangements. [Disponibil Online] la: http://www.eurofound.europa.eu/observatories/eurwork/comparative-information/flexibleforms-of-work-very-atypical-contractual-arrangements.

Burgess, J., Campbell, I. 1998. The nature and dimensions of precarious employment in Australia, Labourand Industry: A Journal of the Social and Economic Relations of Work, 8(3), 5-21.

Chan S., Tweedie, D.2015. PrecariousWorkand Reproductive Insecurity. Social Alternatives, 34 (4). https://doi.org/10.1080/10301763.1998.10669175.

Ciucă, V. (coord). 2016. Studiu referitor la nivelul salariului minim brut garantat în plată în România prin evaluarea efectelor economice și sociale ale aplicării acestuia. Disponibil online la http://www.mmuncii.ro/j33/images/Documente/Transparenta/2016/Studiu_salariu_minim_proi ect.pdf.

Della Porta et. al. 2015. The New Social Division Makingand Unmaking Precariousness, Palgrave Macmillan.

EC. 2018. Study to Monitor the Economic Development of the Collaborative Economy at sector level in the 28 EU Member States, Luxembourg: Publications Office of the European Union, Luxembourg.

EU-OSHA. 2017. Protecting workers in the online platform economy: An overview of regulatory and policy developments in the EU, Publications Office of the European Union, Luxembourg.

Eurofound. 2017. Sixth European Working Conditions Survey - Overview report (2017 update), Publications Office of the European Union, Luxembourg. 
Eurofound. 2018. Employment and working conditions of selected types of platformwork, Publications Office of the European Union, Luxembourg.

Harvey, D. 2005. A Brief History of Neoliberalism, Oxford, Oxford University Press.

Guga, S. et al. 2018. Situația salariaților, studiu anual. Syndex România.

Kalleberg, A. 2011. Goodjobs, badjobs: The rise of polarizedandprecariousemploymentsystems in the United States, 1970s-2000s. New York, NY: Russell.

Kalleberg, A. L. 2009. Precarious Work, Insecure Workers: Employment Relations in Transition, American Sociological review, 74, 1-22. https://doi.org/10.1177/000312240907400101.

Murgia, A. 2012. Between Workand Nonwork: Precarious Transitions through Life Storiesand Everyday Life. Narrative works, issues, inverstigations \& interventions, 2(2), 41-61. Disponibil online la https://www.semanticscholar.org/paper/Between-Work-and-Nonwork\%3A-PrecariousTransitions-Murgia/b1898a45c0c1585efb6b34b6cc2d548ba503763e.

Murgia, A., Poggio, B. 2018. Genderand Precarious Research Careers. A Comparative Analysis. London: Routledge.

Pesole, A., Urzì Brancati, C., Fernández-Macías, E., Biagi, F. And González Vázquez, I.. 2018. Platformworkers in Europe: Evidence from the COLLEEM survey, Joint Research Centre, Publications Office of the European Union, Luxembourg.

Piarom. 2018. Studiu privind dinamica pieței muncii la nivelul principalelor industrii angajatoare din România în perioada 2016-2017. Disponibil online la https:/www.piarom.ro/wp-content/uploads/ 2018/07/1.Studiu-privind-forta-de-munca-2017-principalele-industrii.pdf?x39362.

Quinlan, M. et al. 2001. The global expansion of precarious employment, work disorganization, and consequences for occupational health: Placing the debate in a comparative historical context. International Journal of Health Services, 31(3), 507-536. https://doi.org/10.2190/22BK9XC0-AK7L-M6QH.

Rodgers, G. 1989. Precariouswork in Western Europe: The state of the debate. In: G. Rodgers \& J. Rodgers (Eds.), Precarious jobs in labour market regulation: the growth of atypical employment in Western Europe (pp. 1-16). Geneva: ILO.

Standing, G. 2011. The Precariat: The New Dangerous Class. Bloomsbury Academic studies among wagedandsalariedworkers.

Trif, A. 2013. Romania: collectivebargaininginstitutionsunderattack. Transfer: European Review of LabourandResearch 19.2 (2013): 227-237 https://doi.org/10.1177/1024258913480600.

Trif, A. 2016. Surviving frontal assault on collectivebargaininginstitutions in Romania: The case of manufacturing companies, European Journal of Industrial Relations, 22(3) 221-234 https:// doi.org/10.1177/0959680116643207.

Tucker, D. 2002. "Precarious" non-standard employment - A review of theliterature. Wellington, New Zealand: Labour Market Policy Group, Department of Labour [Disponibil online] la: http://www.dol.govt.nz/publication-view.asp?.

Vallas, S.2015. Accounting for precarity: Recent studies of labor market uncertainty. Contemporary Sociology, 44(4), 463-46. doi:10.1177/0094306115588484a.

Vosko, L. F. 2006. Precariousemployment. Understandinglabour market insecurity in Canada. Montreal: McGill-Queen's University Press.

Zamfir, C. 2015. Spre o nouă teorie a tranziţiei, în: Stănescu, I. and Zamfir, C. (coord.). 2015. România la răscruce: opţiuni pentru viitor. București, Pro Universitaria.

*** Codul Fiscal 227/2015, actualizat in ian. 2019.

*** Directiva 77/2016, privind condițiile de muncă ale lucrătorilor pe platforme digitale în România.

*** Legea Dialogului Social nr. 62/2011.

$* * *$ Legea nr. 53 / 2003 Codul muncii.

*** Legea nr. 81/2018 privind reglementarea tele-muncii.

*** Legea zilierilor 52/2011 actualizată în 2019. 
he article intends to critically analyse the implications of
economic precariousness integrated into the platform work of
food-delivery sector. The recent context of labour market crisis caused by the COVID-19 virus and assisted by the labour policy changes have brought recently on the public agenda the subject of digital employment. However, at the academic level, this subject has been sporadically analysed, marginalizing the dimensions related to the risks and vulnerabilities associated with the precarization effect on digital work. Therefore, by combining different analytical angles, focusing on the socio-economic conditions and vulnerability of workers from the food-delivery sector, the article aims a synthetic analysis of the association between precarious work, the accelerated digitization of work caused by COVID-19 and the phenomenon of flexible employment. Thus, there are two approaches in the proposed article demonstration: first, the article will provide information on the political and economic context of the Romanian labour market before the COVID-19 pandemic crisis and will present the current situation of precarious employment and minimum wage policy. Secondly, the analysis will be focused on digital employment in the platform-based food-delivery sector in Romania, with a case study on the delivery staff situated in the first line exposure to the COVID-19 virus.

Keywords: precariousness; platform work; flexibility; COVID-19 virus; minimum wage. 